\title{
Nitrogen availability and early corn growth on plowed and no-till soils amended with different types of cover crops
}

\author{
Shiva Ladan ${ }^{1}$, Pierre-André Jacinthe ${ }^{1 *}$ \\ ${ }^{1}$ Department of Earth Sciences, Indiana University Purdue University, Indianapolis (IUPUI), $723 \mathrm{~W}$. Michigan \\ Street, SL 118, IN 46202. USA. *Corresponding author: pjacinth@iupui.edu
}

\begin{abstract}
Heavy application of nitrogen $(\mathrm{N})$ fertilizers to agroecosystems contributes to water pollution and emission of nitrous oxide $\left(\mathrm{N}_{2} \mathrm{O}\right)$, an atmospheric constituent implicated in the greenhouse effect and stratospheric ozone depletion. The incorporation of cover crops biomass into agricultural soil is a practice that could provide a portion of the $\mathrm{N}$ needed by growing crops, and thereby could help reduce $\mathrm{N}$ fertilizer input and $\mathrm{N}$ loss from agroecosystems. Although the cover crop composition and the tillage management history of receiving soils could affect the pattern of mineral $\mathrm{N}$ release and its fates, these questions have not been addressed in previous research. A greenhouse experiment $(85 \mathrm{~d})$ was conducted to investigate the effects of two cover crops, hairy vetch (Vicia villosa, C/N: 11) and rye (Secale cereale, $\mathrm{C} / \mathrm{N}: 82$ ) on mineral $\mathrm{N}$ flux, $\mathrm{N}_{2} \mathrm{O}$ emission, and corn growth in soils under no-till (NT, 11 years) and plow-till (PT). Overall, tillage practice had only a marginal influence on $\mathrm{N}$ dynamics. Although $\mathrm{NO}_{3}^{-}$flux was enhanced by both cover crops, the $\mathrm{NO}_{3}^{-}$released was more efficiently utilized in the rye treatment. Corn growth and $\mathrm{N}$ uptake were significantly greater $(\mathrm{P}<0.02 ; 1.5$ times $)$ with rye compared to the vetch treatment. Conversely, $\mathrm{N}_{2} \mathrm{O}$ emission was significantly $(\mathrm{P}<0.03)$ higher with vetch than rye addition, with cumulative emission (across PT and NT) averaging $2.45 \mathrm{~kg} \mathrm{~N}^{-1}$ with vetch and $1.28 \mathrm{~kg} \mathrm{~N}^{-1}$ with rye addition. Positive relationships were found between $\mathrm{NO}_{3}^{-}$flux and $\mathrm{N}_{2} \mathrm{O}$ emission, with the slopes of the regression lines suggesting a greater propensity of $\mathrm{NO}_{3}^{-}$released from vetch to be converted into $\mathrm{N}_{2} \mathrm{O}$. By leading to less $\mathrm{N}_{2} \mathrm{O}$ emission and better corn $\mathrm{N}$ uptake, the study results indicate that rye is a better cover crop option than vetch, regardless of tillage practice.
\end{abstract}

Keywords: Tillage practices, cover crop, nitrogen management, nitrous oxide 


\section{Introduction}

In modern agriculture, application of nitrogen $(\mathrm{N})$ fertilizer is needed to maintain crop productivity, but this activity has well-documented impacts on water quality and greenhouse gases (GHG) emission including nitrous oxide $\left(\mathrm{N}_{2} \mathrm{O}\right)$, an atmospheric constituent implicated in global climate warming and stratospheric ozone depletion (Smith et al., 2007). Although only a small portion (less than $3 \%$ ) of applied $\mathrm{N}$ fertilizer is typically emitted as nitrous oxide $\left(\mathrm{N}_{2} \mathrm{O}\right)$, these emissions can be considerable on national and global scales given the heavy reliance of modern agriculture on synthetic $\mathrm{N}$ fertilizer (Robertson et al., 2000). It has been estimated that agriculture contributes $58 \%$ of the total anthropogenic $\mathrm{N}_{2} \mathrm{O}$ emission (Smith et al., 2007).

Since $\mathrm{N}_{2} \mathrm{O}$ emission tends to be positively correlated with $\mathrm{N}$ fertilizer application rates (Millar et al., 2010), reduction in $\mathrm{N}$ fertilizer input might be an effective way of mitigating $\mathrm{N}_{2} \mathrm{O}$ emission, but this strategy could result in decreased crop yields, and thus not likely to be acceptable to farmers (Millar et al., 2010). There are some alternative practices which could help mitigate $\mathrm{N}_{2} \mathrm{O}$ emission without reducing crop yields, such as optimization of fertilizer source in relation to tillage practices (Venterea et al., 2011), application of slowrelease fertilizers (Halvorson et al., 2010), and changing the depth of fertilizer placement (Omonode et al., 2011). The effectiveness of these practices in reducing $\mathrm{N}_{2} \mathrm{O}$ emission varies depending on local conditions and other factors. Work by Millar et al., (2010) showed a non-linear exponential increase in $\mathrm{N}_{2} \mathrm{O}$ emission when fertilizer is applied in excess of crop $\mathrm{N}$ demand for optimum production. Therefore, downward adjustments of $\mathrm{N}$ fertilizer application rate are needed in order to reduce agricultural $\mathrm{N}_{2} \mathrm{O}$ emission. However, reduction in the rate of synthetic $\mathrm{N}$ fertilizer application must consider other strategies to providing growing crops with the amount of mineral $\mathrm{N}$ they need for optimum yield.
Cover crop could be a natural source of mineral $\mathrm{N}$ and provides an alternative management strategy to reduce synthetic $\mathrm{N}$ addition and $\mathrm{N}_{2} \mathrm{O}$ emission from agroecosystems. In a cover-crop system, cereal and/or legume crops are grown during the dormant season for the purpose of scavenging residual nutrients. At the end of its life cycle, the cover crop is killed and plant nutrients are progressively released from the decomposing cover crop biomass, and become available to the succeeding cash crop. The rate of mineral $\mathrm{N}$ release and its fate depend, among other factors, on tillage practices and cover crop composition.

Cover crop residue returned to agricultural soils provides organic substrates to fuel microbial activity, and therefore can affect $\mathrm{N}$ cycling processes. Through its influence on soil microbial biomass composition and activity, tillage practices can influence cover crop biomass decomposition, the dynamics (mineralization/ immobilization) of soil mineral $\mathrm{N}$, and ultimately $\mathrm{N}$ availability to growing crops. Past studies have generally documented higher mineral $\mathrm{N}$ content, greater rate of organic matter mineralization, and increased propensity for $\mathrm{N}$ leaching under plowed-till (PT) (Tracy et al., 1990), whereas long-term no-till (NT) has also been shown to result in enhanced $\mathrm{N}$ cycling efficiency and net $\mathrm{N}$ immobilization (Baggs et al., 2003; Hayatsu et al., 2008). These differences in $\mathrm{N}$ cycling are thought to be the result of higher soil moisture, lower oxygen and soil temperature in NT compared to PT soils. Bavin et al., (2009) evaluated the impact of tillage and winter rye (Secale cereale) on $\mathrm{N}_{2} \mathrm{O}$ emission, and noted that emission was mainly affected by $\mathrm{N}$ application rate, with limited difference between PT and reduced tillage (RT). Due to their effect on soil biological properties, tillage practices could influence the timing and the amount of $\mathrm{N}$ released from decomposing cover crop biomass. 
In addition to tillage practices, the chemical composition of cover crops must also be considered when assessing their impact on gaseous emissions. The carbon/ nitrogen $(\mathrm{C} / \mathrm{N})$ ratio and lignin content of plant residue are important variables that could determine $\mathrm{N}$ mineralization kinetics in soil ecosystems. The linkage between cover crop mineralization and $\mathrm{N}_{2} \mathrm{O}$ emission has been shown to be dependent on the $\mathrm{C} / \mathrm{N}$ ratio and the lignin: $\mathrm{N}$ ratio of cover crop residue, with negative correlations generally reported between these parameters and $\mathrm{N}_{2} \mathrm{O}$ emission (Huang et al., 2004; Millar and Baggs, 2004). Huang et al., (2004) studied the effect of five crop residues with different $\mathrm{C} / \mathrm{N}$ ratios (range: 8 to 118) on $\mathrm{N}$ mineralization, and measured the highest $\mathrm{N}_{2} \mathrm{O}$ emission with rapeseed (lowest $\mathrm{C} / \mathrm{N}$ ratio) and the lowest emission with sugarcane (highest $\mathrm{C} / \mathrm{N}$ ratio). It has also been shown that at $\mathrm{C} / \mathrm{N}$ ratios in the 20-30 range, the net $\mathrm{N}$ immobilization and $\mathrm{N}$ mineralization tend to be of similar magnitude (Tracy et al., 1990; Hayatsu et al., 2008; Partey et al., 2014), suggesting that cover crop with $\mathrm{C} / \mathrm{N}$ ratios $<20$ can lead to net $\mathrm{N}$ mineralization whereas biomass with $\mathrm{C} / \mathrm{N}$ ratios $>30$ would most likely result in $\mathrm{N}$ immobilization. These laboratory data were later supported by an empirical model that predicted less $\mathrm{N}_{2} \mathrm{O}$ emission from crop residues with high $\mathrm{C} / \mathrm{N}$ ratios (Mu et al., 2009).

As suggested by the literature reviewed above, in order to implement cover crop as a farming practice, one needs to account for both the cover crop composition $(\mathrm{C} / \mathrm{N}$ ratio) and the tillage management history of receiving agricultural soils. In other words, the interaction of cover crop type (grass vs legume) and tillage management could determine $\mathrm{N}$ cycling direction (immobilization/mineralization) and mineral $\mathrm{N}$ availability. It is of great importance to understand the timing of mineral $\mathrm{N}$ release following termination of cover crop in agroecosystems, as this could lead to better synchronization between $\mathrm{N}$ availability and $\mathrm{N}$ demand by the subsequent crop (e.g. corn).
To investigate these questions, a greenhouse experiment was conducted using soils under plow-till (PT) and no-till (NT) amended with either a cereal or a legume cover crop (different $\mathrm{C} / \mathrm{N}$ ratios), and the fate of $\mathrm{N}$ from cover crop was investigated. The following fates were considered for cover crop $\mathrm{N}$ : gaseous emission $\left(\mathrm{N}_{2} \mathrm{O}\right), \mathrm{N}$ mineralization, and $\mathrm{N}$ assimilation by vegetation. Plant uptake was taken as a measure of $\mathrm{N}$-use efficiency, and thus considered as the most desirable outcome. It is hypothesized that the legume cover crop (low $\mathrm{C} / \mathrm{N}$ ratio) is more suitable for the NT soil, whereas cereal cover crop (with high $\mathrm{C} / \mathrm{N}$ ratio) is preferable for the PT. The overall goal of this study was to identify the best cover crops for fields under NT and PT.

\section{Materials and Methods}

\subsection{Greenhouse experiment design}

This experiment was conducted in a greenhouse using surface soil $(0-25 \mathrm{~cm})$ collected in October 2014 from agricultural fields at Starkey Farms in Hendricks county, Indiana (39 $\left.51^{\prime} 49^{\prime \prime} \mathrm{N}, 86^{\circ} 21^{\prime} 31^{\prime \prime} \mathrm{W}\right)$. Management practices at these fields included conventional tillage (plow-till, PT) and no-till (NT, 11 years). Chemical properties of the PT soil were: $\mathrm{pH}=6.41$, total $\mathrm{C}=13.3$ $\pm 2.3 \mathrm{~g} \mathrm{C} \mathrm{kg}^{-1}$ soil, and total $\mathrm{N}=1.9 \pm 0.6 \mathrm{~g} \mathrm{~N} \mathrm{~kg}^{-1}$ soil. Chemical properties of NT soil were: $\mathrm{pH}=7.42$, total $\mathrm{C}=18.5 \pm 2.3 \mathrm{~g} \mathrm{C} \mathrm{kg}^{-1}$ soil, and total $\mathrm{N}=1.7 \pm 0.2 \mathrm{~g} \mathrm{~N}$ $\mathrm{kg}^{-1}$ soil. Soils at the sampling sites were intergraded between the silt-loam Crosby (aeric Epiaqualf) and the loamy Brookston (typic Argiaquoll) series. At the bottom of each pot (H: $37 \mathrm{~cm}$; diam: $49.7 \mathrm{~cm}$; area: $\left.1940 \mathrm{~cm}^{2}\right)$ a layer $(5 \mathrm{~cm})$ of acid-washed pea gravel, on top of which was placed a soil block extracted from either the NT or the PT field. Soil was extracted with care taken to minimize disturbance and preserve soil structure. Pots were transported to the greenhouse, irrigated daily for 7 days before cover crop addition. 
The experiment involved soil from 2 tillage practices (NT, PT) and 2 cover crops (rye and hairy vetch). For each tillage, a control (with no cover crop added) was included. Each treatment was run in triplicate. Thus, a total of 18 pots was used in the experiment to accommodate the experimental factors. At the beginning of the experiment, each pot was amended with a solution of potassium nitrate $\left(\mathrm{KNO}_{3}\right)$ and dipotassium phosphate $\left(\mathrm{K}_{2} \mathrm{HPO}_{4}\right)$ to provide an equivalent $20 \mathrm{~kg} \mathrm{~N} \mathrm{ha}^{-1}$ and $10 \mathrm{~kg} \mathrm{Pha}^{-1}$. A second application of $40 \mathrm{~kg} \mathrm{~N} \mathrm{ha}^{-1}$ as ammonium nitrate $\left(\mathrm{NH}_{4} \mathrm{NO}_{3}\right)$ was made 60 days after the experiment started as the pool of mineral $\mathrm{N}$ was depleted and the corn plants began to show signs of nutrient deficiency.

\subsection{Cover crops collection and corn planting}

The cover crops selected for this study are among the most commonly-used in US Midwest agricultural fields ((http://mccc.msu.edu/species/), and included hairy vetch (Vicia villosa) (C: 42\%; N: 3.8\%) and rye (Secale cereale) (C: $82 \%$; N: 1\%). Rye and vetch biomass (shoots and roots) was air and oven-dried $\left(65^{\circ} \mathrm{C}\right)$, and shredded into small pieces $(1-3 \mathrm{~cm})$. An amount of $10 \mathrm{~g}$ of cover crop biomass was added to each pot $(\sim 500 \mathrm{~kg}$ dry matter $\mathrm{ha}^{-1}$, equivalent to 19 and $5 \mathrm{~kg} \mathrm{~N} \mathrm{ha}^{-1}$ as vetch and rye biomass, respectively). No cover crop was added to the control pots. The cover crop biomass was spread on the soil surface and mixed slightly with the first $\mathrm{cm}$ of soil to simulate the termination of a cover crop by roller/crimper. The next day, 3 corn seeds (Zea mays var. $d$ warf) were planted in each pot. Following germination, two plants were removed leaving the most vigorous corn seedling in each pot. Pots were irrigated once a week to keep the gravimetric soil moisture between $25-35 \%$. The temperature in the greenhouse was maintained between $18-23^{\circ} \mathrm{C}$, and light was provided for $12 \mathrm{~h}$ each day during the experiment. Corn height was measured on day 60 , and at the end of the experiment (day 85). At that time, corn biomass was harvested, shoots and roots were separated, washed, oven-dried $\left(65^{\circ} \mathrm{C}\right.$ until constant weight) and the dry weight recorded to determine standing crop biomass. Subsamples of leaf/root biomass were pulverized using a rolling grinder, and the fine powder was stored for $\mathrm{C}$ and $\mathrm{N}$ analysis.

\subsection{Soil mineral nitrogen monitoring}

Soil mineral nitrogen $\left(\mathrm{NH}_{4}^{+}\right.$and $\left.\mathrm{NO}_{3}^{-}\right)$was monitored on a weekly basis using cation and anion $\mathrm{PRS}^{\mathrm{TM}}$-probes obtained from Western Ag Innovations Inc (Saskatoon, Canada). Mineral N absorbed by the PRS-probes simulates the amount of mineral $\mathrm{N}$ intercepted by plant roots. One anion and one cation PRS-probe was labeled and inserted in each pot ( $\approx 10 \mathrm{~cm}$ depth) within 1-2 cm of corn roots. Every week, PRS-probes were removed from the pots and immediately transported to the laboratory for elution. PRS-probes were washed with deionized (DI) water to remove soil particles from the membranes, and eluted with $17.5 \mathrm{~mL}$ of $\mathrm{HCl}(0.5$ $\mathrm{N}$ ) in a zip lock bag. After $1 \mathrm{~h}$, the eluate from each bag was transferred to a $20 \mathrm{~mL}$ clean plastic vial and stored frozen until analyzed. PRS-probes were cleaned in (1 h soaking and shaking in $0.5 \mathrm{~N} \mathrm{HCl}$ ) and regenerated (soaking in $0.5 \mathrm{~N} \mathrm{NaHCO}_{3}$ ). Regenerated PRS-probes were rinsed with deionized water and returned to the pots the same day they were removed. During the experiment, three anion and cation PRS-probes were kept in a sealed bag containing deionized water as blanks in a refrigerator. PRS-probe eluates were analyzed for $\mathrm{NH}_{4}^{+}$and $\mathrm{NO}_{3}$. Weekly mineral $\mathrm{N}$ flux (F, $\mu \mathrm{g} \mathrm{N} \mathrm{cm}{ }^{-2}$ ) was computed as follows:

$$
F=(C)\left(\frac{V}{S}\right)
$$

where $C$ is the mineral $\mathrm{N}\left(\mathrm{NH}_{4}+\right.$ and $\left.\mathrm{NO}_{3}^{-}\right)$concentration in the eluate $\left(\mu \mathrm{g} \mathrm{N} \mathrm{mL} L^{-1}\right), V$ is the volume of eluent per probe $(17.5 \mathrm{~mL})$, and $S$ is the surface area of each probe $\left(17.5 \mathrm{~cm}^{2}\right)$. 
Soil samples (0-5 and 5-10 cm) were collected from each pot (on day 60) to determine soil mineral $\mathrm{N}$ content. Soil samples were sieved $(2 \mathrm{~mm}$ sieve), and a subsample (10 g) extracted with 30 $\mathrm{mL}$ of $\mathrm{KCl}(1 \mathrm{M})$ solution. Soil extracts were analyzed for $\mathrm{NH}_{4}^{+}$and $\mathrm{NO}_{3}^{-}$.

\subsection{Nitrous oxide fluxes monitoring}

During the experiment, $\mathrm{N}_{2} \mathrm{O}$ flux was measured weekly using the static chamber method. Static chambers consisted of PVC cylinders ( $\mathrm{H}: 15 \mathrm{~cm}$; diameter: $10 \mathrm{~cm}$ ) were inserted $\sim 5 \mathrm{~cm}$ into each pot, leaving a headspace of about $10 \mathrm{~cm}$. During sampling, chambers were closed with PVC lids secured to the base with bungee cords and clamps. The lid was fitted with a gasket at its underside edge to make an air-tight seal, and with a butyl rubber septa at its center to form a sampling port. Chamber headspace was sampled 0, 45 and 90 min after closure, and air samples were stored in evacuated $10 \mathrm{~mL}$ glass vials. Concentration of $\mathrm{N}_{2} \mathrm{O}$ was measured by gas chromatography (electron detector capture, ECD). Daily fluxes of $\mathrm{N}_{2} \mathrm{O}$ (F) $\left(\mu \mathrm{g} \mathrm{N}_{2} \mathrm{O} \mathrm{cm}^{-2}\right.$ hour $\left.^{-1}\right)$ were computed as:

$$
F=\frac{d C}{d t} \frac{V}{A} k
$$

where $\mathrm{d} C / \mathrm{d} t$ is the $\mathrm{N}_{2} \mathrm{O}$ concentration change in chamber headspace $\left(\mu \mathrm{g} \mathrm{N}_{2} \mathrm{O}-\mathrm{N} \mathrm{m}^{-3} \mathrm{~min}^{-1}\right), V$ is the chamber volume $\left(\mathrm{m}^{3}\right), A$ is the area of soil circumscribed by chamber $\left(\mathrm{m}^{2}\right)$, and $k$ is the time conversion factor (1440 $\left.\mathrm{min}_{\text {day }}{ }^{-1}\right)$ (Fisher et al., 2014).

\subsection{Analytical methods}

Soil $\mathrm{pH}$ was measured using a soil suspension (1:2 soil to water) and an Accumet- $25 \mathrm{pH} /$ ion meter.

To determine total $\mathrm{C}$ and $\mathrm{N}$ in soil and plant samples, an aliquot of each crushed soil/plant sample that passed through a $150-\mu \mathrm{m}$ sieve was weighed (soil samples 7-9 $\mathrm{mg}$, plant samples 2-3 mg) into a tin capsule, and analyzed for $\mathrm{C}$ and $\mathrm{N}$ contents by dry combustion $\left(960^{\circ} \mathrm{C}\right)$ using a Vario-Cube analyzer (Elementar Americas, New Jersey, USA). Total $\mathrm{N}$ in the standing corn biomass was computed as:

Corn $N$ uptake $\left(\mathrm{kg} \mathrm{N} \mathrm{ha}^{-1}\right)=\frac{\text { mass of } N \text { in shoot and root }(\mathrm{g})}{\text { pot surface area }\left(\mathrm{cm}^{2}\right)} \times \frac{1(\mathrm{~kg})}{10^{3}(\mathrm{~g})} \times \frac{10^{8}\left(\mathrm{~cm}^{2}\right)}{1(\mathrm{ha})}$

Air samples from the static chambers were analyzed using a CP-3800 gas chromatograph (Varian Inc, Palo Alto, CA) interfaced with a Combipal headspace auto-sampler (CTC Analytics) and equipped with an electron capture detector (Jacinthe et al., 2015). The stationary phase consisted of a pre-column (L: $0.3 \mathrm{~m}$; i.d.: $2 \mathrm{~mm}$ ) and an analytical column (L: $1.8 \mathrm{~m}$; i.d.: 2 $\mathrm{mm}$ ) filled with Porapak Q (80-100 mesh).

Operating conditions of the gas chromatograph were as follows: carrier gas ( $\mathrm{UHP} \mathrm{N}_{2}$ at $60 \mathrm{ml} \mathrm{min}^{-1}$ ), oven temperature (90 $\left.{ }^{\circ} \mathrm{C}\right)$, detector temperature $\left(300{ }^{\circ} \mathrm{C}\right)$. The gas chromatograph was calibrated using certified $\mathrm{N}_{2} \mathrm{O}$ standards $(0.1,0.5$ and $1 \mu \mathrm{L}$ $\mathrm{N}_{2} \mathrm{O} \mathrm{L}^{-1}$ ) obtained from Matheson Tri-Gas. Eluates from the PRS-probes and $\mathrm{KCl}$ soil extracts were analyzed for $\mathrm{NH}_{4}^{+}$and $\mathrm{NO}_{3}{ }^{-}$using US EPA method 350.2 and 353.1, respectively on a photometric analyzer (Aquakem 20, EST Analytical, Fairfield, $\mathrm{OH}, \mathrm{USA})$. 


\subsection{Statistical analysis}

Data were first tested for normality using the normality test available in SigmaPlot ver. 13 (Systat, San Jose, CA). Since most of the data were not normally distributed, Kruskal-Wallis test was used to determine the significance of the experimental factors (tillage practice and cover crop) on $\mathrm{N}_{2} \mathrm{O}$ and mineral nitrogen $\left(\mathrm{NH}_{4}^{+}\right.$and $\left.\mathrm{NO}_{3}^{-}\right)$fluxes and corn growth. The Kruskal-Wallis test was followed by Mann-Whitney pairwise test when a significant difference was detected. Unless otherwise noted, statistical significance was determined at $\alpha=0.05$. Statistical tests were conducted using PAST software (ver. 2.17c) downloaded from http://nhm2.uio.no/norlex/ past/download.html (University of Oslo).
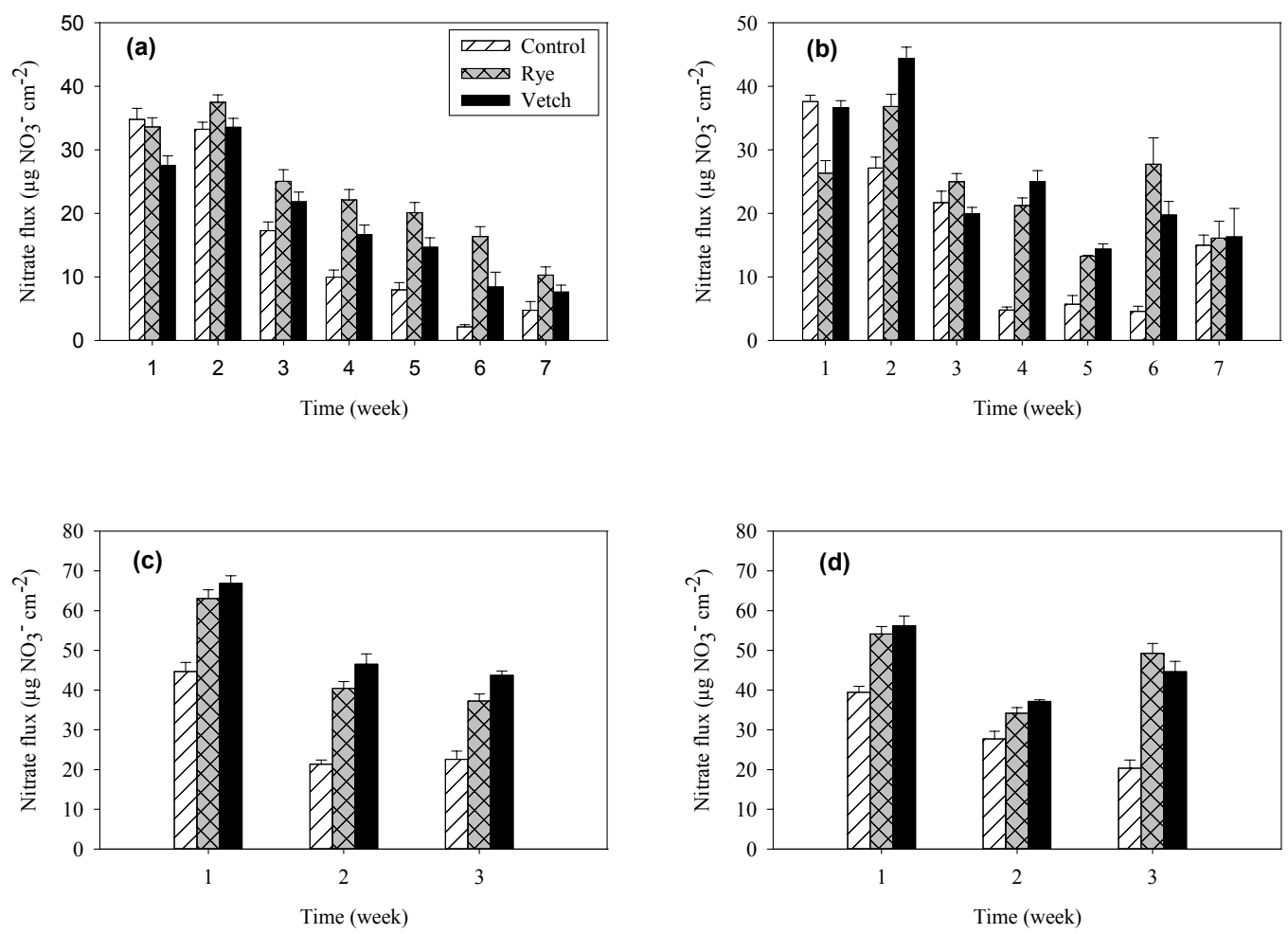

Figure 1. Weekly nitrate flux in plowed-till (PT) (a, c), and no-till (NT) (b, d) soils; control and amended with rye or vetch. Results are reported for the first 60 days of the experiment $(a, b)$, and for the period between day 60 and harvest on day $85(\mathrm{c}, \mathrm{d})$. An application of $40 \mathrm{~kg} \mathrm{~N} \mathrm{ha}^{-1}$ as ammonium nitrate was made on day 60, when corn plants began to show signs of $\mathrm{N}$ deficiency. Error bars represent SD from a mean of three replicates. 


\section{Results}

\subsection{Soil mineral nitrogen flux}

Ammonium concentration in the PRS-probes eluates were near zero in most cases. Therefore, no further description of this mineral $\mathrm{N}$ species is provided. However, $\mathrm{NO}_{3}^{-}$concentrations were detected and measured in the samples taken by the anion PRSprobes during the experiment. Results of $\mathrm{NO}_{3}^{-}$flux are presented in two phases; phase 1 for the first 60 days of the experiment, and phase 2 for the period between day 60 and 85 (Figure 1).

During phase 1 , similar pattern in $\mathrm{NO}_{3}^{-}$flux was observed with both PT and NT soils (Figures $1 \mathrm{a}$ and $1 \mathrm{~b}$ ), i.e. high $\mathrm{NO}_{3}$ - flux during the first two weeks and then gradual decrease in all treatments. This gradual decrease was generally most visible in PT soil (Figure 1a). A few short-lived spikes in $\mathrm{NO}_{3}^{-}$flux was observed during the first 2 weeks of the experiment, especially in the vetch-treated NT soils (Figure 1b). Although higher $\mathrm{NO}_{3}{ }^{-}$fluxes were recorded in the cover crop amendment than in the controls during the first two or three weeks of the experiment, difference in $\mathrm{NO}_{3}^{-}$- flux between controls and cover crop treatments was not significant $(\mathrm{P}>0.05)$ different during that period (Figures. 1a and 1b). However, from week three to the end of phase 1, cover crop amended treatments showed significantly higher $\mathrm{NO}_{3}^{-}$flux than controls in both PT and NT soils (Figure 1). No significant difference $(\mathrm{P}=0.12)$ was observed between the two types of cover crops with regard to $\mathrm{NO}_{3}^{-}$flux (Table 1).

Table 1. Average weekly nitrate flux in plowed-till (PT) and no-till (NT) soils non-amended (control) and amended with either rye or vetch as cover crop. Results are reported for the first 60 days of the experiment (phase 1), and for the period between day 60 and harvest on day 85 (phase 2). An application of $40 \mathrm{~kg} \mathrm{~N} \mathrm{ha}^{-1}$ as ammonium nitrate was made on day 60 , when corn plants began to show signs of $\mathrm{N}$ deficiency. For each tillage practice, values in a column are significantly different $(\mathrm{P}<0.05)$ if followed by different letters.

\begin{tabular}{|c|c|c|c|}
\hline \multirow{2}{*}{ Tillage } & \multirow[t]{2}{*}{ Cover crop } & \multicolumn{2}{|c|}{$\begin{array}{l}\text { Average nitrate flux } \\
\left(\mu \mathrm{g} \mathrm{NO} 3^{-} \mathrm{cm}^{-2}\right)\end{array}$} \\
\hline & & Phase 1 & Phase 2 \\
\hline \multirow[t]{3}{*}{ PT } & Control & $15.74 \mathrm{~b}$ & $29.53 b$ \\
\hline & Rye & $23.58 \mathrm{a}$ & $46.92 \mathrm{a}$ \\
\hline & Vetch & $18.62 \mathrm{a}$ & $52.37 \mathrm{a}$ \\
\hline \multirow[t]{3}{*}{ NT } & Control & $16.65 b$ & $29.16 b$ \\
\hline & Rye & $23.79 a$ & $45.83 \mathrm{a}$ \\
\hline & Vetch & $25.21 \mathrm{a}$ & $45.99 \mathrm{a}$ \\
\hline
\end{tabular}


As stated previously, an application of mineral $\mathrm{N}$ fertilizer was made on day 60 to alleviate symptoms of $\mathrm{N}$ deficiency. Not surprisingly, a marked increase in $\mathrm{NO}_{3}$ - flux was observed the week following fertilizer application, and the $\mathrm{N}$ flux gradually decreased over time (Figures 1c, 1d). Again, during that period (phase 2), $\mathrm{NO}_{3}^{-}$flux was significantly $(\mathrm{P}<0.05)$ higher in the cover crop treatments compared to controls, but the cover crop treatments were not significantly different from each other $(\mathrm{P}=0.09)$. Although $\mathrm{NO}_{3}^{-}$flux was generally higher in NT than PT soil, no significant difference $(\mathrm{P}=0.10)$ between the tillage practices was detected (Table 1). Averaged across tillage practices, $\mathrm{NO}_{3}^{-}$flux was 2 times higher with cover crop application compared to controls (Table 1). Although difference was not always significant, $\mathrm{NO}_{3}^{-}$flux was generally higher in the pots treated with rye than in those treated with vetch (Figure 1, Table 1).

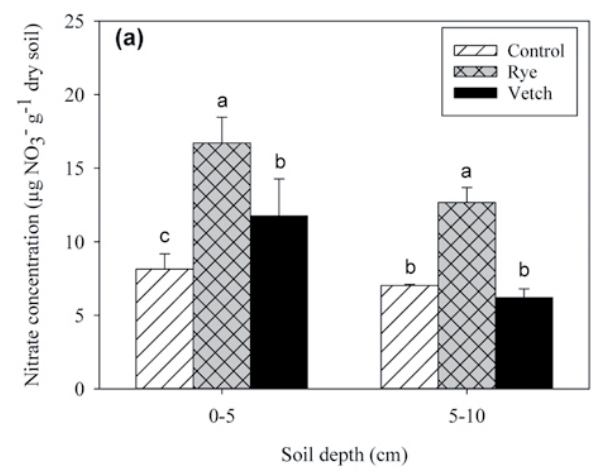

Measurements of $\mathrm{NO}_{3}$ - concentration made on day 60 showed that most of the $\mathrm{NO}_{3}^{-}$pool was in the first $5 \mathrm{~cm}$ soil layer (Figure 2). This depth distribution suggests limited $\mathrm{NO}_{3}^{-}$leaching and accumulation at depth during the experiment. Irrespective of tillage practice, $\mathrm{NO}_{3}$ - concentration in the $0-5 \mathrm{~cm}$ layer was significantly higher $(\mathrm{P}<0.05)$ under cover crop treatments compared to controls (Figure 2). In almost all cases, $\mathrm{NO}_{3}{ }^{-}$concentration was significantly higher $(\mathrm{P}<0.05)$ with rye amendment compared to vetch treatment (Figure 2).

The hairy vetch biomass was almost completely decomposed during the first 60 days of the experiment (phase 1) with only a few stems left on the soil surface. However, rye residue was still observable and persisted to the end of the experiment (day 85).

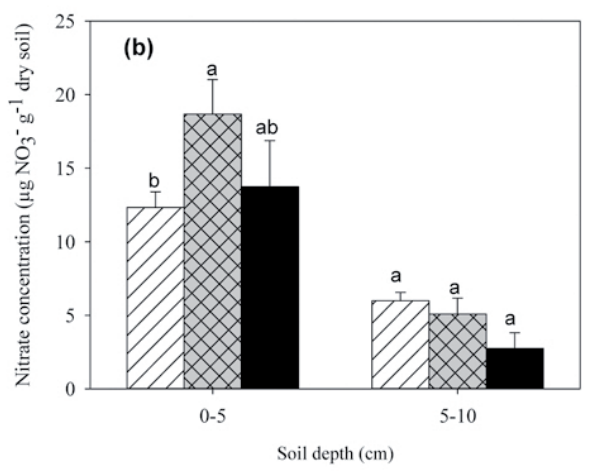

Figure 2. Nitrate concentration in plowed-till (PT) (a) and no-till (NT) (b) soils; control and amended with rye or vetch. Soil samples were taken from different depth $(0-5 \mathrm{~cm}$ and 5-10 cm) on the day 60 and before the second fertilizer application event. Error bars represent SD from a mean of three replicates. 


\subsection{Nitrous oxide flux}

During the first phase of the experiment (days 0-60), $\mathrm{N}_{2} \mathrm{O}$ fluxes were the highest in the first two (PT soil, Figure 3a) and three (NT soil, Figure 3b) weeks, and then gradually decreased over time in all treatments. Regardless of tillage, $\mathrm{N}_{2} \mathrm{O}$ flux was higher in the cover crop treatments compared to controls. Between the two cover crops, the highest $\mathrm{N}_{2} \mathrm{O}$ fluxes (up to $23 \mu \mathrm{g} \mathrm{N}_{2} \mathrm{O} \mathrm{cm}^{-2} \mathrm{~h}^{-1}$ ) were observed in the vetch treatments (Figures. 3a and 3b), but significant difference $(\mathrm{P}<0.05)$ between the cover crops was mostly limited to the first two weeks. Following $\mathrm{N}$ fertilizer application on day 60 (phase 2), $\mathrm{N}_{2} \mathrm{O}$ fluxes increased again (Figures. $3 \mathrm{c}$ and $3 \mathrm{~d}$ ), and most noticeably in the rye-amended PT soil (Figure 3c). This burst in $\mathrm{N}_{2} \mathrm{O}$ emission was very short-lived, lasting only one week before $\mathrm{N}_{2} \mathrm{O}$ fluxes gradually stabilized at around $<1 \mu \mathrm{g} \mathrm{N}_{2} \mathrm{O} \mathrm{cm}^{-2} \mathrm{~h}^{-1}$ in all treatments.
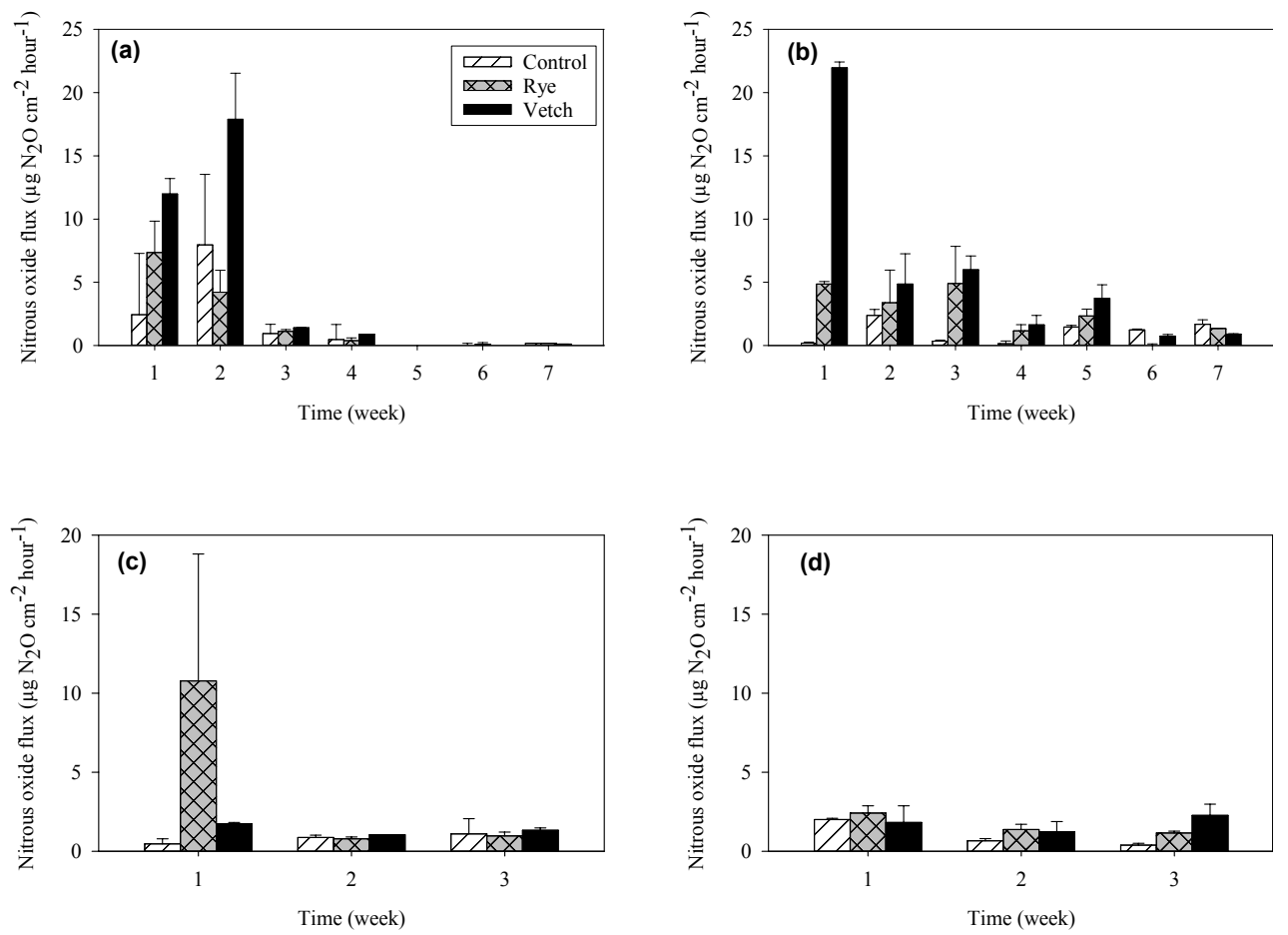

Figure 3. Nitrous oxide flux in plowed-till (PT) (a, c), and no-till (NT) (b, d) soils; control and amended with rye or vetch. Results are reported for the first 60 days of the experiment $(a, b)$, and for the period between day 60 and harvest on day 85 (c, d). An application of $40 \mathrm{~kg} \mathrm{~N} \mathrm{ha}^{-1}$ as ammonium nitrate was made on day 60, when corn plants began to show signs of $\mathrm{N}$ deficiency. Error bars represent SD from a mean of three replicates. 
Cumulative $\mathrm{N}_{2} \mathrm{O}$ emission (Table 2) during the experiment was significantly $(\mathrm{P}<0.05)$ higher in the vetch treatment compared to rye and control. This trend was observed regardless of tillage practice, although a borderline tillage $\mathrm{x}$ cover crop interaction was noted during phase 1 . In the absence of cover crop addition, cumulative $\mathrm{N}_{2} \mathrm{O}$ averaged 0.85 and $0.57 \mathrm{~kg} \mathrm{~N} \mathrm{ha}^{-1}$ respectively in the PT and NT soil, with only a marginal increase from phase 1 to phase 2 (Table 2). In the NT soil, the vetch treatment resulted in a cumulative $\mathrm{N}_{2} \mathrm{O}$ emission of 2.54 and $2.88 \mathrm{~kg} \mathrm{~N} \mathrm{ha}^{-1}$ during phase 1 and phase 2, respectively (Table 2). The rye treatment resulted in slightly lower emission averaging 1.15 and $1.46 \mathrm{~kg}$ $\mathrm{N} \mathrm{ha}{ }^{-1}$ for these respective periods. A similar trend was observed in the PT, with cumulative emission on average 2 times higher with vetch than with rye addition (Table 2).

Table 2. Cumulative nitrous oxide emission in plowed-till (PT) and no-till (NT) soils non-amended (control) and amended with either rye or vetch as cover crop. Results are reported for the first 60 days of the experiment (phase 1), and for the period between day 60 and harvest on day 85 (phase 2). An application of $40 \mathrm{~kg} \mathrm{~N}^{-1}$ as ammonium nitrate was made on day 60 , when corn plants began to show signs of $\mathrm{N}$ deficiency. For each tillage practice, values in a column are significantly different $(\mathrm{P}<0.05)$ if followed by different letters.

\begin{tabular}{|c|c|c|c|}
\hline \multirow{2}{*}{ Tillage } & \multirow{2}{*}{ Cover crop } & \multicolumn{2}{|c|}{$\begin{array}{l}\text { Cumulative nitrous oxide emission } \\
\left(\mu \mathrm{g} \mathrm{N} \mathrm{N} \mathrm{cm}_{2}\right)^{\dagger}\end{array}$} \\
\hline & & Phase 1 & Phase 2 \\
\hline \multirow[t]{3}{*}{ PT } & Control & $12.07 \mathrm{~b}$ & $14.52 \mathrm{c}$ \\
\hline & Rye & $13.39 \mathrm{~b}$ & $25.94 b$ \\
\hline & Vetch & $32.32 \mathrm{a}$ & $36.44 a$ \\
\hline \multirow[t]{3}{*}{ NT } & Control & $7.48 \mathrm{c}$ & $10.55 \mathrm{c}$ \\
\hline & Rye & $18.04 \mathrm{~b}$ & $22.99 b$ \\
\hline & Vetch & $39.88 \mathrm{a}$ & $45.22 \mathrm{a}$ \\
\hline
\end{tabular}

$\dagger$ Multiply by 0.06 to convert to $\mathrm{kg} \mathrm{N}_{2} \mathrm{O}-\mathrm{N} \mathrm{ha}^{-1}$.

As stated above, the vetch treatment resulted in both higher $\mathrm{NO}_{3}^{-}$flux and higher $\mathrm{N}_{2} \mathrm{O}$ flux than rye. It follows that strong positive relationships $\left(r^{2}>0.66\right)$ were found between these variables with the PT soil (Figure 4). It should be noted that only a weak trend between these variables was observed with the NT soil. The slope of the relationships was nearly 3 times higher in the vetch compared to the rye treatment, indicating a greater propensity of $\mathrm{NO}_{3}{ }^{-}$release from vetch to be converted into $\mathrm{N}_{2} \mathrm{O}$ (Figure 4). 

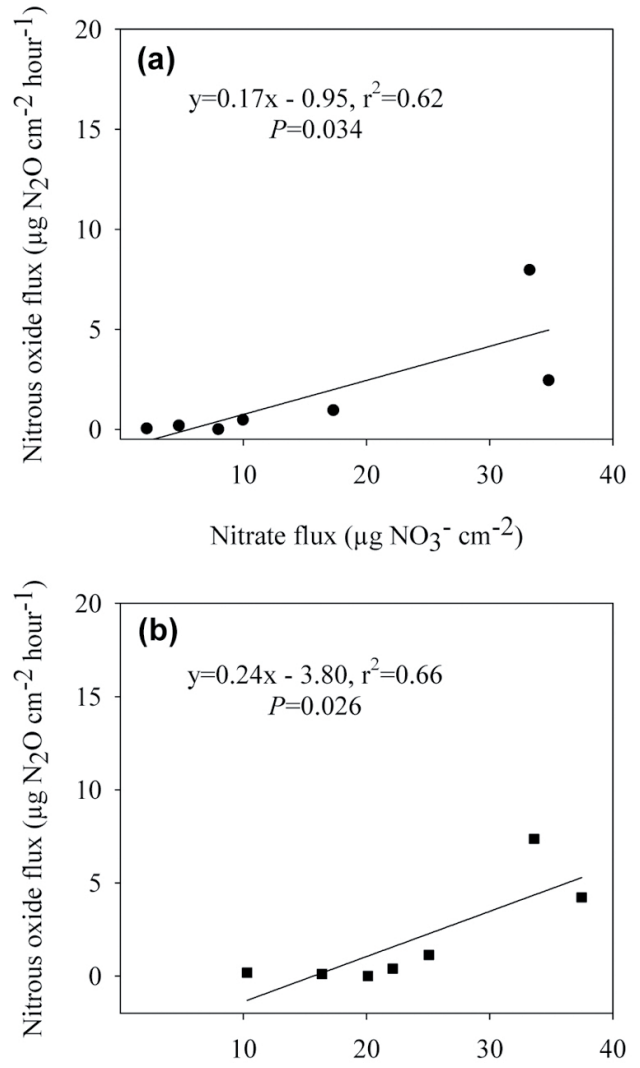

Nitrate flux $\left(\mu \mathrm{g} \mathrm{NO}_{3}{ }^{-} \mathrm{cm}^{-2}\right)$

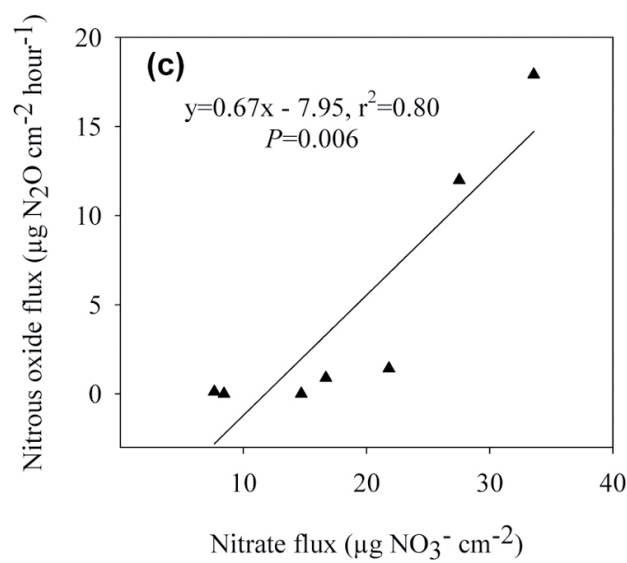

Figure 4. Relationships between nitrate flux and nitrous oxide emission in plowed-till (PT) soil; (a) control, (b) rye-amended, and (c) vetch-amended, during the first 60 days of the experiment.

\subsection{Corn shoot and root biomass}

Regardless of tillage practice, corn grown in the ryeamended pots had significantly $(\mathrm{P}<0.02)$ greater biomass (height as well) than those in the control and vetch-treated pots (Table 3). The shoot/root ratios (Table 3) were also much greater with the rye treatments compared to vetch and control. Corn height and shoot/root ratios were not significantly affected by tillage, although under rye amendment corn biomass was generally greater in PT than in NT. In both PT and NT soils, corn biomass was in the order rye $>$ vetch $>$ control (Table 3 ).

Although $\mathrm{N}$ content and $\mathrm{C} / \mathrm{N}$ ratio of corn tissues (shoot and root) were generally similar regardless of treatment, the amount of $\mathrm{N}$ in the standing biomass was markedly higher in corn plants grown under cover crop treatments (Table 4). Results of total N uptake by corn plants in both PT and NT soils were in the order: rye $>$ vetch $>$ control (Table 4 ). This trend is consistent with the observation that corn growth was significantly better with rye amendment compared to vetch (Table 3). N uptake was generally higher in corn grown in NT than PT soil (Table 4).

\section{Discussion}

\subsection{Decomposition rate of cover crop biomass}

Two months after the experiment began, the hairy vetch biomass was almost completely decomposed (>90\%), whereas a good portion of the rye residue remained on the soil surface in the experimental pots. This observation is similar to those reported in several previous studies (Zougmore et al., 2006; Nagumo and Nakamura 2013) in which only $5 \%$ of hairy vetch residue typically remained at the end of a corn season. These results indicate the rapid mineralization and early release of mineral $\mathrm{N}$ from hairy vetch $(\mathrm{C} / \mathrm{N}$ : 
Table 4. Amount of $\mathrm{N}$ in the biomass of corn grown for 85 days in pots (1 plant per pot) filled with plowed-till (PT) and no-till (NT) soils non-amended (control) and amended with either rye or vetch as cover crop. Carbon content of corn shoot and root averaged $448.1 \pm 18.6$ and $411.8 \pm 14.4 \mathrm{~g} \mathrm{C} \mathrm{kg}^{-1}$, respectively. For each tillage practice, values in a column are significantly different $(\mathrm{P}<0.05)$ if followed by different letters.

\begin{tabular}{|c|c|c|c|c|c|c|c|c|c|}
\hline \multirow[t]{2}{*}{ Tillage } & \multirow[t]{2}{*}{$\begin{array}{l}\text { Cover } \\
\text { crop }\end{array}$} & \multicolumn{3}{|l|}{ Shoot } & \multicolumn{3}{|l|}{ Root } & \multicolumn{2}{|c|}{$\begin{array}{l}\text { Amount of } \mathrm{N} \text { in standing } \\
\text { corn biomass }\end{array}$} \\
\hline & & $\begin{array}{l}\text { N content } \\
\left(\mathrm{g} \mathrm{N} \mathrm{g}^{-1} \mathrm{dm}\right)^{\dagger}\end{array}$ & $\begin{array}{l}\text { Biomass } \\
(\mathrm{g} \mathrm{dm})\end{array}$ & $\begin{array}{l}\text { Mass of } \mathrm{N} \\
\text { in shoot }(\mathrm{g})\end{array}$ & $\begin{array}{l}\mathrm{N} \text { content } \\
\left(\mathrm{g} \mathrm{N} \mathrm{g}^{-1} \mathrm{dm}\right)\end{array}$ & $\begin{array}{l}\text { Biomass } \\
(\mathrm{g} \mathrm{dm})\end{array}$ & $\begin{array}{l}\text { Mass of N } \\
\text { in root }(\mathrm{g})\end{array}$ & $\left(\mathrm{g} \mathrm{N} \mathrm{pot}^{-1}\right)$ & $\left(\mathrm{kg} \mathrm{N} \mathrm{ha}^{-1}\right)^{\mathrm{b}_{+}^{\ddagger}}$ \\
\hline \multirow[t]{3}{*}{ PT } & Control & 0.10 & 16.73 & $1.71 \mathrm{c}$ & 0.08 & 2.84 & $0.22 b$ & 1.93 & $99.48 \mathrm{c}$ \\
\hline & Rye & 0.08 & 65.47 & $5.34 \mathrm{a}$ & 0.08 & 3.92 & $0.31 \mathrm{a}$ & 5.65 & $291.24 \mathrm{a}$ \\
\hline & Vetch & 0.08 & 37.88 & $2.94 b$ & 0.07 & 4.79 & $0.35 \mathrm{a}$ & 3.29 & $169.59 \mathrm{~b}$ \\
\hline \multirow[t]{3}{*}{ NT } & Control & 0.08 & 9.43 & $0.73 \mathrm{c}$ & 0.08 & 2.09 & $0.17 \mathrm{~b}$ & 0.9 & $46.39 \mathrm{c}$ \\
\hline & Rye & 0.13 & 47.59 & $6.40 \mathrm{a}$ & 0.07 & 3.24 & $0.22 b$ & 6.62 & $341.24 \mathrm{a}$ \\
\hline & Vetch & 0.11 & 43.88 & $4.73 b$ & 0.09 & 5.54 & $0.47 \mathrm{a}$ & 5.2 & $268.06 \mathrm{~b}$ \\
\hline
\end{tabular}

$\dagger$ dm: dry matter

\$ Amount of $\mathrm{N}$ in standing biomass expressed on an area basis using pot surface area $\left(1940 \mathrm{~cm}^{-2}\right)$

11), and from the biomass of other leguminous cover crops that have low $\mathrm{C} / \mathrm{N}$ ratios. This rapid decomposition of vetch may have led to the high $\mathrm{NO}_{3}^{-}$fluxes measured at the beginning of the experiment (Figure 1 and Table 1). This enhancement in $\mathrm{NO}_{3}^{-}$release was likely due to the sudden exposure of soil microbes to a large supply of $\mathrm{C}$ and $\mathrm{N}$-rich substrates, including easily decomposable non-protein $\mathrm{N}$ and soluble protein N. Lee et al., (2002) noted that vetch lost $72-81 \%$ of its initial weight one month after application, leading to the conclusion that hairy vetch could be a substitute $\mathrm{N}$ starter fertilizer but not a sustainable $\mathrm{N}$ source due to its fast decomposition. Results of several past studies (Lee et al., 2002; Ruffo and Bollero 2003; Muhammad et al., 2011) suggested that, due to its higher $\mathrm{N}$ concentration, the leaf portion of crop residue decomposes faster than the stem and root portions. Although these factors may have played a role in the observed physical loss of cover crop mass, this cannot be accounted for in the present study because the cover crop applied was a mixture of stems and leaves. Further, under field conditions, cover crop roots remain buried in the soils as they undergo decomposition; therefore, the N-supplying capacity of hairy vetch (and other legume cover crops) may last longer than the results of the present study would suggest.

\subsection{Mineral nitrogen release: Relative significance of tillage practice and cover crop composition}

As noted previously, $\mathrm{NH}_{4}^{+}$flux was negligible in almost all treatments. That was an unexpected result that could be due to the rapid nitrification of the $\mathrm{NH}_{4}^{+}$ evolved from ammonification of organic N. A study by Sainju et al., (2007), in which $\mathrm{NH}_{4}^{+}$fertilizer was applied, reported similar results; significant accumulation of $\mathrm{NH}_{4}^{+}$was only detected in treatments receiving $\mathrm{N}$ fertilizer in the $120-130 \mathrm{~kg} \mathrm{~N} \mathrm{ha}^{-1}$ application rates, 2-fold greater than the amount applied in the present experiment.

The observed enhancement in $\mathrm{NO}_{3}^{-}$release with cover crop addition (Figure 1; Table 1) is in accord with 
the findings of Frimpong et al., (2011) who reported increased $\mathrm{NO}_{3}^{-}$release following soil incorporation of maize residue. Similar to the temporal pattern observed in the present study, pulses in soil $\mathrm{NO}_{3}^{-}$ were short-lived, generally lasting two weeks or less (Frimpong et al., 2011). In other words, following cover crop addition, $\mathrm{N}$ mineralization occurred rapidly due to the large amount of readily mineralizable $\mathrm{C}$ and $\mathrm{N}$ supplied by the fresh biomass, but the process decreased substantially over time as mineralized $\mathrm{N}$ was presumably consumed by growing corn plants and soil microorganisms.

Due to their chemical composition and generally low fiber content (Lee et al., 2002), the biomass of legume plants should decompose faster than that of cereals. Observations consistent with that expectation were made in this experiment, as nearly all hairy vetch biomass was decomposed in about 7 weeks. In contrast, the rye biomass lasted much longer. These results suggest that $\mathrm{N}$ contained in hairy vetch biomass may have been released very rapidly, before the corn seedlings could fully utilize the available N. In contrast, decomposition and mineral $\mathrm{N}$ release with rye were more gradual and better synchronized with corn plants development. Similar patterns were reported in a study by Ruffo and Bollero (2003) in which hairy vetch and rye decomposition and $\mathrm{NO}_{3}^{-}$release were compared. These authors (Ruffo and Bollero, 2003) concluded that rye was a more suitable material than vetch with regard to $\mathrm{N}$ supply to plants and soil conservation. In a decomposition study involving these same plant materials, Kuo and Sainju (1998) noted that rye, as a cover crop, could increase the crossover time of net $\mathrm{N}$ mineralization (i.e. the time when the amount of net $\mathrm{N}$ mineralized in the residue-amended soil is equal to that of control). Therefore, with rye addition the release of mineral $\mathrm{N}$ is more sustained, and its timing is better synchronized with crop $\mathrm{N}$ needs in the early growth phase. Vidal and Lopez (2005) noted that, due to the slow $\mathrm{N}$ release, rye could be a more appropriate cover crop to prevent $\mathrm{NO}_{3}^{-}$leaching and water pollution. Therefore, from a soil fertility standpoint, rye can be proposed as a better cover crop option than vetch. A central hypothesis of this study was that tillage management history could dictate the performance of different types of cover crops applied to agricultural soils. Specifically, it was hypothesized that legume cover crops (low $\mathrm{C} / \mathrm{N}$ ratio) would be more suitable for NT soils, and that cereal cover crops (high $\mathrm{C} / \mathrm{N}$ ratio) would be preferable for soils under conventional tillage (PT). The study results did not, however, support that hypothesis. In this study, tillage management (PT and NT) did not significantly affect $\mathrm{NO}_{3}^{-}$ flux (Figure 1; Table 1) and had a marginal effect on $\mathrm{N}_{2} \mathrm{O}$ emission (Table 2). These results are in accord with the findings of Dalal et al., (2011) who reported no significant effect of tillage practices (NT and PT) on mineral $\mathrm{N}$ release from agricultural soils in which crop residue was retained. However, in another study (Sainju et al., 2007), involving vetch and rye as cover crops in NT and PT soils, higher $\mathrm{NO}_{3}{ }^{-}$concentration was measured in PT soil with vetch incorporation than in the other treatments. Further, higher rate of $\mathrm{N}$ leaching was also reported in the vetch compared to the rye treatment (Sainju et al., 2007). Several authors have therefore proposed a mixture of rye and vetch for either NT or PT system (Ruffo and Bollero, 2003; Vidal and Lopez, 2005; Sainju et al., 2007). Results of the present study concur with that suggestion.

Both rye and vetch treatments resulted in $\mathrm{NO}_{3}$ - fluxes and soil $\mathrm{NO}_{3}$ - pool 1.5 to 2-fold higher than controls (Table 1). These results demonstrated that cover crops can be a source of $\mathrm{N}$ for growing crops, and therefore inclusion of cover crops in farming systems could result in a reduction of $\mathrm{N}$ fertilizer applied to agricultural soils. That should prove economically and environmentally beneficial given the deleterious ecological impacts of increased reactive $\mathrm{N}$ in natural systems. 
Although cover crop can be advocated as a viable $\mathrm{N}$ management strategy (Lee et al., 2002; Sainju et al., 2007), it is important to recognize that the practice can, for most crops, only provide a portion of the needed N. As stated previously, $\mathrm{N}$ fertilizer had to be applied around day 60 in this experiment when corn growth was visibly impaired by a lack of mineral N.

\subsection{Nitrous oxide emission: Relative significance of tillage practice and cover crop composition}

In accord with several past studies (Muhammad et al., 2011; Mitchell et al., 2013), $\mathrm{N}_{2} \mathrm{O}$ fluxes were highest in the 2-3 weeks following fertilizer application, and higher in the cover crop treatment than controls (Figure 3). Largely a product of denitrification in soils, the intensity of $\mathrm{N}_{2} \mathrm{O}$ production is often controlled by the availability of $\mathrm{NO}_{3}^{-}$and organic $\mathrm{C}$ to support the activity of heterotrophic denitrifiers. It has been suggested that increased $\mathrm{N}_{2} \mathrm{O}$ emission in cover cropamended soils could be linked to increased availability of labile $\mathrm{C}$ to denitrifiers as a result of cover crop application (Mitchell et al., 2013). Although the cover crops did not significantly differ with regard to $\mathrm{N}_{2} \mathrm{O}$ emission, vetch (low $\mathrm{C} / \mathrm{N}$ ratio) addition resulted in higher $\mathrm{N}_{2} \mathrm{O}$ flux compared to rye (high $\mathrm{C} / \mathrm{N}$ ratio) (Figure 3). A similar negative trend between cover crop $\mathrm{C} / \mathrm{N}$ ratio and $\mathrm{N}_{2} \mathrm{O}$ flux was reported by Huang et al., (2004). This result is also in accord with the finding of Zschornack et al., (2011) who, in an investigation of $\mathrm{N}_{2} \mathrm{O}$ emission from soils treated with the legume species serradella and ryegrass, measured higher emission with the legume cover crop. These results are also in agreement with those of others (Constantinides and Fownes, 1994; Millar and Baggs, 2004), and the general negative relationship between $\mathrm{N}_{2} \mathrm{O}$ emission and $\mathrm{C} / \mathrm{N}$ ratio of crop residue (Huang et al., 2004). Additionally, results of the present study showed strong positive relationships between $\mathrm{N}_{2} \mathrm{O}$ emission and $\mathrm{NO}_{3}^{-}$flux, as a measure of mineral $\mathrm{N}$ availability (Figure 4). The slope of the relationship was much steeper (3 times) in vetch-amended (Figure 4c) soil compared to rye (Figure $4 b$ ). This is an important and novel observation, and it underscores the propensity of $\mathrm{NO}_{3}^{-}$evolved in the vetch treatment to undergo denitrification. That could be due to greater biodegradability of vetch-derived organic $\mathrm{C}$, as well as poor synchronization between crop needs and the timing of $\mathrm{NO}_{3}^{-}$release from decomposing vetch biomass. When plant $\mathrm{N}$ uptake is negligible, the conversion of $\mathrm{NO}_{3}^{-}$to $\mathrm{N}_{2} \mathrm{O}$ becomes the most favored fate. Finally, it is conceivable that the composition of the soil denitrifying population was differently affected by each type of cover crop, and that ultimately may have resulted in variable enhancement in $\mathrm{N}_{2} \mathrm{O}$ production. To assess the merit of that contention, laboratory-scale investigations must be conducted to examine shifts in the size and diversity of the denitrifying community in soils treated with cover crops of varying composition. Cumulative $\mathrm{N}_{2} \mathrm{O}$ emission was not significantly affected by tillage practices, but was strongly related to the type of cover crop. Several studies have reported statistically significant interactions between cover crop and tillage practice, with higher $\mathrm{N}_{2} \mathrm{O}$ emission generally observed with reduced tillage than with $\mathrm{PT}$ under similar cover crop treatment (Bavin et al., 2009; Abdalla et al., 2012). During phase 2 of the present study, a borderline interaction between these factors was detected (Table 2). However, the most striking observation is the consistently lower (2 times on average) $\mathrm{N}_{2} \mathrm{O}$ emission with rye compared to vetch. The lower $\mathrm{N}_{2} \mathrm{O}$ emission with rye (and other biomass with higher $\mathrm{C} / \mathrm{N}$ ratios) could be linked to $\mathrm{N}$ immobilization (Zschornack et al., 2011; Partey et al., 2014) as well as more efficient use of $\mathrm{N}$ by plants. As long as this $\mathrm{N}$ immobilization does not result in a complete exhaustion of the mineral $\mathrm{N}$ pool (thus impeding plant growth), this should be viewed as beneficial because 
it leads to the retention of $\mathrm{N}$ which otherwise could be lost from the soil system as $\mathrm{N}$ gases. These results have significant management implications and support the view that, rye adoption as a cover crop, could help mitigate $\mathrm{N}_{2} \mathrm{O}$ emission from agricultural soils.

\subsection{Effects of cover crop addition on corn growth}

Cover crop addition resulted in significant improvement in corn growth and $\mathrm{N}$ uptake (Tables 3 and 4). Nearly all parameters related to corn growth were 4-5 times greater in the cover crop treatments compared to control (Table 3). Similar results have previously been reported (Lee et al., 2002; Nagumo and Nakamura, 2013). The enhancement in corn growth with cover crops application can be ascribed to greater $\mathrm{N}$ availability to growing plants. Providing strong support for that interpretation is the consistently greater biomass production and the higher $\mathrm{N}$ uptake (2-5 times) measured in cover crop-treated corn than in controls (Tables 3 and 4). These results confirm the positive effects of cover crops on corn growth, and these beneficial effects were more prominent in the rye than in the vetch treatments. Improved corn growth with rye amendment could be due to the greater resistance of rye to decomposition (compared to vetch) allowing the release of $\mathrm{N}$ to occur over a period of time that is longer and better matches with plant $\mathrm{N}$ needs. As noted above, vetch addition also resulted in increased $\mathrm{N}$ uptake but much less so than with rye. As the data presented in Figure 4 suggest, instead of being incorporated into corn biomass, a non-negligible portion of vetch-derived $\mathrm{N}$ is denitrified resulting in higher cumulative $\mathrm{N}_{2} \mathrm{O}$ loss.

During the experiment, the amount of $\mathrm{N}$ added as cover crop biomass was $<20 \mathrm{~kg} \mathrm{~N} \mathrm{ha}^{-1}$, and that amendment was the only difference between the control and the treatments. Inspection of the data presented in Table 4 showed that the difference in $\mathrm{N}$ uptake between treatments and controls is 6-8 times greater than the amount of $\mathrm{N}$ added in the cover crop. This observation suggests that the impact of cover crop on plant $\mathrm{N}$ nutrition could far outweigh the amount of $\mathrm{N}$ contained in the cover crop biomass. Through its effect on soil microbes and enzyme activity, cover crop addition could stimulate the conversion of native soil $\mathrm{N}$ into available $\mathrm{N}$ for plant uptake. This view would be consistent with the concept of added nitrogen interaction (ANI) that was suggested by Jenkinson et al., (1985). Future studies, using ${ }^{15} \mathrm{~N}$-labelled cover crop biomass, should be conducted to examine this mechanism and underlying processes.

\section{Conclusions}

The present study was undertaken with the overall objective of identifying the type of cover crop most suitable to agricultural soils under different tillage practices. In comparison to controls (without cover crop), application of cover crop biomass resulted in enhanced $\mathrm{NO}_{3}^{-}$flux, higher corn $\mathrm{N}$ uptake and $\mathrm{N}_{2} \mathrm{O}$ emission, but the extent of these enhancements was largely dependent on the cover crop composition and not on tillage practice. While no significant effect of tillage practices was detected, the increase in $\mathrm{NO}_{3}^{-}$and $\mathrm{N}_{2} \mathrm{O}$ fluxes was significantly higher in soil treated with vetch than with rye. On the other hand, corn growth was better and $\mathrm{N}$ incorporation into corn biomass was significantly $(\mathrm{P}<0.02)$ greater with rye amendment comparted to vetch addition. Overall, these results indicate that, regardless of tillage practices, rye is a better cover crop option than vetch for enhancing soil fertility and $\mathrm{N}$ nutrition of corn.

\section{Acknowledgements}

Funding for this study was provided through USDANational Research Initiative (NRI) grant 2009-3511205213. Authors thank Mike Starkey for granting access 
to his fields. Field and laboratory assistance of Dr. Jia Du and Erika Harbison is gratefully acknowledged.

\section{References}

Abdalla, M., Rueangritsarakul, K., Jones, M., Osborne, B., Helmy, M., Roth, B., Bruke, J., Nolan, P., Smith, P., Williams, M. 2012. How effective is reduced tillage-cover crop management in reducing N2O fluxes from arable crop soils?. Water Air Soil Pollut. 223, 5155-5174.

Baggs, E.M., Stevenson, M., Pihlatie, M., Cook, H., Cadisch, G. 2003. Nitrous oxide emissions following application of residue and fertilizer under zero and conventional tillage. Plant Soil. 254, 361-370.

Bavin, T.K., Griffis, T.J., Baker, J.M., Venterea, T.M. 2009. Impact of reduced tillage and cover cropping on the greenhouse gas budget of a maize/ soybean rotation ecosystem. Agric. Ecosyst. Environ. 134, 234-242.

Constantinides, M., Fownes, J.H. 1994. Nitrogen mineralization from leaves and litters of tropical plants- relationship to nitrogen, lignin, and soluble polyphenol concentrations. Soil Biol. Biochem. 26, 49-55.

Dalal, R.C., Allen, D.E., Wang, W.J., Reeves, S., Gibson, I. 2011. Organic carbon and total nitrogen stocks in a Vertisol following 40 years of no-tillage, crop residue retention and nitrogen fertilization. Soil. Till. Res. 112, 133-139.

Fisher, K., Jacinthe, P.A., Vidon, P., Liu, X., Baker, M.E. 2014. Nitrous oxide emission from cropland and adjacent riparian buffers in contrasting hydrogeomorphic settings. J. Environ. Qual. 43, 338-348.

Frimpong, K.A., Yawson, D.O., Baggs, E.M., Agyarko, K. 2011. Foes incorporation of cowpea-maize residue mixes influences nitrous oxide emission and mineral nitrogen release in a tropical Luvisol? Nutr. Cycl. Agroecosyst. 91, 281-292.
Halvorson, A.D., Del Grosso, S.J., Alluvione, F. 2010. Nitrogen source effects on nitrous oxide emissions from irrigated no-till corn. J. Environ. Qual. 39, 1554-1562.

Hayatsu, M., Tago, K., Saito, M. 2008. Various players in the nitrogen cycle: Diversity and functions of the microorganisms involved in nitrification and denitrification. Soil Sci. Plant Nutr. 54, 33-45.

Huang, Y., Zou, J., Zheng, X., Wang, Y., Xu, X. 2004. Nitrous oxide emissions as influenced by amendment of plant residues with different $\mathrm{C} / \mathrm{N}$ ratios. Soil Biol. Biochem. 36, 973-981.

Jenkinson, D.S., Fox, R.H., Raynar, J.H. 1985. Interactions between fertilizer nitrogen and soil nitrogen - the so-called 'priming' effect. J. Soil Sci. $36,425-444$.

Kuo, S., Sainju, U.M. 1998. Nitrogen mineralization and availability of mixed leguminous and nonleguminous cover crop residues in soil. Biol. Fert. Soils. 26, 346-353.

Lee, H.J., Lee, J.S., Seo, J.H. 2002. Decomposition and $\mathrm{N}$ release of hairy vetch applied as a green manure and its effects on rice yield in paddy field. Korean J. Crop Sci. 47, 137-141.

Millar, N., Baggs, E.M. 2004. Chemical composition, or quality, of agroforestry residue influences $\mathrm{N}_{2} \mathrm{O}$ emissions after their addition to soil. Soil Biol. Biochem. 36, 935-943.

Millar, N., Robertson, G.P., Grace, P.R., Gehl, R.J., Hoben, J.P. 2010. Nitrogen fertilizer management for nitrous oxide $\left(\mathrm{N}_{2} \mathrm{O}\right)$ mitigation in intensive corn (maize): production: An emission reduction protocol for US Midwest agriculture. Mitig. Adapt. Strateg. Glob. Chang. 15, 185-204.

Mitchell, D.C., Castellano, M.J., Sawyer, J.E., Pantoja, J. 2013. Cover crop effects on nitrous oxide emissions: role of mineralizable carbon. Soil Sci. Soc. Am. J. 77, 1765-1773. 
Mu, Z., Huang, A., Kimura, S.D., Jin, T., Wei, S., Hatano, R. 2009. Linking $\mathrm{N}_{2} \mathrm{O}$ emission to soil mineral $\mathrm{N}$ as estimated by $\mathrm{CO}_{2}$ emission and soil $\mathrm{C} / \mathrm{N}$ ratio. Soil Biol. Biochem. 41, 2593-2597.

Muhammad, W., Vaughan, S.M., Dalal, R.C., Menzies, N.W. 2011. Crop residues and fertilizer nitrogen influence residue decomposition and nitrous oxide emission from a Vertisol. Biol. Fert. Soils. 47, 15-23.

Nagumo, F., Nakamura, K. 2013. Nitrogen balance under no-tillage maize (Zea mays L.) cultivation after hairy vetch (Vicia villosa Roth) cropping at sloping fields. Soil Sci. Plant Nutr. 59, 249-261.

Omonode, R.A., Smith, D.R., Gal, A., Vyn, T.J. 2011. Soil nitrous oxide emissions in corn following three decades of tillage and rotation treatments. Soil Sci. Soc. Am. J. 75, 152-163.

Partey, S.T., Preziosi, R. F., Robson, G.D. 2014. Improving maize residue use in soil fertility restoration by mixing with residues of low $\mathrm{C}$-to- $\mathrm{N}$ ratio: effects on $\mathrm{C}$ and $\mathrm{N}$ mineralization and soil microbial biomass. J. Soil. Sci. Plant Nutr. 14, 518-531.

Robertson. G.P, Paul, E.A., Harwood, R.R. 2000. Greenhouse gases in intensive contributions of individual gases to the radiative forcing of the atmosphere. Science. 289, 1922-1925.

Ruffo, M.L., Bollero, G.A. 2003. Modeling rye and hairy vetch residue decomposition as a function of degree-days and decomposition. Agron. J. 95, 900-907.

Sainju, U.M., Singh, B.P., Whitehead, W.F., Wang, S. 2007. Accumulation and crop uptake of soil mineral nitrogen as influenced by tillage, cove crops, and nitrogen fertilization. Agron. J. 99, 682-691.
Smith, P., Martino, D., Cai, Z. 2007. Agriculture. In: Climate Change 2007: Mitigation (eds Metz B., Davidson O.R., Bosch P.R., Dave R., Meyer L.A.). Contribution of Working Group III to the Fourth Assessment Report of the Intergovernmental Panel on Climate Change. Cambridge University Press, Cambridge, United Kingdom.

Tracy, P.W., Westfall, D.G., Elliott, E.T., Peterson, G.A., Cole, C.V. 1990. Carbon, nitrogen, phosphorus, and sulfur mineralization in plow and no-till cultivation. Soil Sci. Soc. Am. J. 54, 457461.

Venterea, R.T., Maharjan, B., Dolan, M.S. 2011. Fertilizer source and tillage effects on yield-scaled nitrous oxide emissions in a corn cropping system. J. Environ. Qual. 40. 1521-1531.

Vidal, M., Lopez, A. 2005. Cover crops and organic amendments to prevent nitrate contamination under a wet climate. Agronomie. 25, 455-463.

Zougmore, R., Nagumo, F., Hosikawa, A. 2006. Nutrient uptake and maize productivity as affected by tillage system and cover crops in a subtropical climate at Ishigaki, Okinawa, Japan. Soil Sci. Plant Nutr. 52, 509-518.

Zschornack, T., Bayer, C., Zanatta, J.A., Vieira, F.C.B., Anghinoni, I. 2011. Mitigation of methane and nitrous oxide emissions from flood-irrigated rice by no incorporation of winter crops residues into the soil. Rev. Bras. Cienc. Solo. 35, 623-634. 